\title{
The use of activated carbons for removing organic matter from groundwater
}

\author{
Jadwiga Kaleta, Małgorzata Kida, Piotr Koszelnik*, Dorota Papciak, Alicja Puszkarewicz, \\ Barbara Tchórzewska-Cieślak
}

Rzeszow University of Technology

*Corresponding author's e-mail: pkoszel@prz.edu.pl

Keywords: groundwater, powdery activated carbon, granular activated carbon, organic matter, biosorption.

\begin{abstract}
The article presents research results of the introduction of powdery activated carbon to the existing technological system of the groundwater treatment stations in a laboratory, pilot plant and technical scale. The aim of the research was to reduce the content of organic compounds found in the treated water, which create toxic organic chlorine compounds (THM) after disinfection with chlorine. Nine types of powdery active carbons were tested in laboratory scale. The top two were selected for further study. Pilot plant scale research was carried out for the filter model using CWZ-30 and Norit Sa Super carbon. Reduction of the organic matter in relation to the existing content in the treated water reached about $30 \%$. Research in technical scale using CWZ-30 carbon showed a lesser efficiency with respect to laboratory and pilot-plant scale studies. The organic matter decreased by $15 \%$. Since filtration is the last process before the individual disinfection, an alternative solution is proposed, i.e. the second stage of filtration with a granular activated carbon bed, operating in combined sorption and biodegradation processes. The results of tests carried out in pilot scale were fully satisfactory with the effectiveness of $70-100 \%$.
\end{abstract}

\section{Introduction}

Groundwater is often the only source of water for public supply. The degree of contamination generally does not allow for its immediate use. Primary groundwater contamination is most often caused by common natural organic substances, mainly humic compounds, which are very difficult to remove with conventional treatment systems (aeration, sedimentation and filtration) (Adamski and Szlachta 2011, Kalda and Murias 2015, Pisarek and Głowacki 2015, Skoczko et al. 2016, Tchórzewska-Cieślak 2012). These contaminants are toxic to humans but their presence in the water can affect the biochemical transformations of elements binding other organic substances and stimulating the development of organisms. Furthermore, they can adsorb toxic compounds including polychlorinated biphenyls, pesticides or phthalates. In addition, humic substances impart the colour and turbidity of water and can emit an undesirable odour (Hur et al. 2006, Grzegorczuk-Nowacka 2011). The danger arising from the presence of humic substances in waters treated for municipal purposes is associated primarily with the formation of oxidation and disinfection of by-products. About 500 different disinfection products are known, most of which are haloacetic acids (HAA) and trihalomethanes (THMs), showing mutagenic and carcinogenic effects for human and animal organisms (Rosińska and Rakocz 2013, Adamski and Szlachta 2011, Grzegorczuk-Nowacka 2011). Consequently, the removal of natural organic materials is a key operation in the development and operation of water treatment processes intended for human consumption (Kim and Yu 2007). Coagulation and adsorption on activated carbon is used for the removal of these substances from water, which involves the formation of biofilm on the surface thereof (Meinel et al. 2010, Jasper et al. 2010, Kovalova et al. 2013, Holc et al. 2016). Biofilm primarily increases the efficiency of water purification and the operation time of carbon beds (Górka et al. 2008, Bodzek and Rajca 2013).

The presence of natural organic matter accounting for the needs of municipal waters is a problem faced by many treatment plants. Hence, the research discussed in the article focused on determining the effectiveness of the removal of humic substances (TOC 14-20 mgC/L) from underground water in the sorption process. The results of laboratory and pilot-plant scale studies on the addition of the powdery activated carbon (PAC) to the existing process water treatment station have been presented.

As an alternative solution, the process of bio-sorption on granular activated carbon (II degree of filtration) was tested in pilot scale.

\section{Materials and methods}

\section{Characteristics of drawn water (raw)}

The Water Treatment Plant (WTP) is supplied from an unconfined quaternary aquifer with a depth of about $15 \mathrm{~m} \mathrm{bgl}$ using 27 wells. The physicochemical composition of water drawn and directed to the treatment station varies greatly, 
because it depends essentially on the well included in the operation and productivity (Table 1). Drawn water does not meet sanitary requirements in terms of turbidity (8.0-14.0 NTU), colour (40-100 $\mathrm{mgPt} / \mathrm{L})$, the permanganate index (11.0-18.1 $\left.\mathrm{mgO}_{2} / \mathrm{L}\right)$, ammonium ion $\left(1.20-1.98 \mathrm{mgNH}_{4}^{+} / \mathrm{L}\right)$, iron $(14.0-44.0 \mathrm{mgFe} / \mathrm{L})$ and manganese $(0.74-2.58 \mathrm{mgMn} / \mathrm{L})$. High water colour, which correlates with the elevated permanganate index value and total organic carbon (TOC; 14-20 $\mathrm{mgC} / \mathrm{L}$ ), indicates the presence of water of natural organic matter that may be present in combinations of complex compounds of iron and manganese. Intakes of iron in the present water are large and rarely seen in the municipal infrastructure. It comes under medium hard water (4.0-9.4 meq/L), with $48-65 \%$ of the hardness being carbonate hardness due to the hardness of the generally drawn water. Raw water also has a high concentration of sulphates $\left(60-240 \mathrm{mgSO}_{4}^{2} / \mathrm{L}\right)$. The physical and chemical composition of the water drawn indicates the difficulties that may arise in the treatment process.

\section{Technology system for water treatment}

The drawn water is directed to a collective well (stoppage time of 2-4 hours, depending on the current water production). The water is then directed to a cascade of oxygenation. A dispensing potassium permanganate chemical-oxidant with a dose of 2.1-2.4 $\mathrm{mg} / \mathrm{L}$ and a PAX-18 coagulant in the amount of $120-140 \mathrm{mg} / \mathrm{L}$ is situated just below the cascade (11.0-12.6 $\mathrm{mgAl} / \mathrm{L})$. Vertical coagulation-sedimentation chambers with a contact time of 6-8 hours are the next stage of the water treatment. Lime milk is dosed (about $10.0 \mathrm{mg} / \mathrm{L}$ ) to the water in the chambers, which is directed to horizontal settler raising the $\mathrm{pH}$. The retention time in the settlers is several hours. The next step involves filtration of water at a speed of $1.5-3 \mathrm{~m} / \mathrm{h}$ and the final disinfection with sodium hypochlorite (Fig. 1).

Although the quality of the treated water which is directed to the water supply meets the requirements of the Regulation of the Minister of Health of 13 November 2015 relating to the quality of water intended for human consumption (Journal of Laws 2015, item. 1989), research has been carried out in order to further reduce the content of organic substances in the treated water of the following composition: TOC $7.00-11.00 \mathrm{mgC} / \mathrm{L}$, with a permanganate index of $4.7-5.0 \mathrm{mgO}_{2} / \mathrm{L}$ and colouring of $10-16 \mathrm{mgPt} / \mathrm{L}$.

\section{The selection and dosing of powdery activated carbons}

Nine powdery activated carbons: Sorbotech LPW 90, Sorbotech LPW 125 CA, CWZ-22, AKPA-22, CWZ-30, Carbopol AP, Norit Sa Super, Hydraffin P 800 and Carbopol MB 5 were examined in the preliminary laboratory tests and were selected on the basis of product cards analysis. Carbon doses amounted to 10,15 and $20 \mathrm{mg} / \mathrm{L}$ and were dosed into the treated water. The best results were obtained with a dose of $20 \mathrm{mg} / \mathrm{L}$, which was used in further tests. Sorbotech LPW 90 (Sorb-1), Sorbotech LPW 125 CA (Sorb-2), CWZ-22, AKPA-22, CWZ-30, Norit Sa Super (Norit), and Carbopol MB 5 carbon proved to be the most effective sorbent of organic compounds. The selected carbon was dosed to the collected water from three sites of the technological system (Fig. 1):

- Point 1 -at the beginning of the technological process after the addition of the $\mathrm{KMnO}_{4}$ oxidant (dose of $2.5 \mathrm{mgO}_{2} / \mathrm{L}$ ) and the PAX-18 coagulant (dose of $130 \mathrm{mg} / \mathrm{L}$ ),

- Point 2 - before the settlers and after the adjustment of $\mathrm{pH}$ with help of $\mathrm{Ca}(\mathrm{OH})_{2}$ (dose of $10 \mathrm{mg} / \mathrm{L}$ ),

- Point 3 - after the settlers, before precipitous filters.

Afterwards, mixing (100 rev/min) was carried out for 60 minutes. The sample was subsequently allowed to achieve an absorption balance for 24 hours. After this time, the solutions were filtered and the effects of the removal of organic compounds were evaluated by determining the colour, permanganate index and the TOC.

\section{Pilot-plant scale studies on the model filter}

In order to make the laboratory tests involving powdery activated carbons reflect real conditions, a model filter F1 (Fig. 2) was made characterized by the construction and hydraulic parameters consistent with the parameters of filters working in the treatment plant. It consisted of a support layer with a height of $0.10 \mathrm{~m}$ and was filled with a double-layer bed: the bottom layer comprised quartz

Table 1. Physicochemical parameters of water used in the test

\begin{tabular}{|c|c|c|c|}
\hline \multirow{2}{*}{ Parameter } & \multirow{2}{*}{ Unit } & \multicolumn{2}{|c|}{ The range of values } \\
\hline & & untreated water & treated water \\
\hline Colour & $\mathrm{mgPt} / \mathrm{L}$ & $40-100$ & $10-16$ \\
\hline Turbidity & NTU & $8.0-14.0$ & 1.0 \\
\hline $\mathrm{pH}$ & - & $6.4-7.0$ & $7.8-8.1$ \\
\hline Temperature & ${ }^{\circ} \mathrm{C}$ & $10.8-12.1$ & $10.9-11.6$ \\
\hline Total hardness & $\mathrm{mgCaCO}_{3} / \mathrm{L}$ & $200-470$ & $280-380$ \\
\hline Sulfates & $\mathrm{mgSO}_{4}^{2-/ L}$ & $60-240$ & $60-124$ \\
\hline Conductivity & $\mathrm{mS} / \mathrm{cm}$ & $430-1016$ & $648-891$ \\
\hline Alkalinity & $\mathrm{mval} / \mathrm{L}$ & $2.5-4.5$ & - \\
\hline Iron & $\mathrm{mgFe} / \mathrm{L}$ & $14.0-44.0$ & $<0.02$ \\
\hline Manganese & $\mathrm{mgMn} / \mathrm{L}$ & $0.74-2.58$ & $<0.02$ \\
\hline Ammonium & $\mathrm{mgNH}_{4}{ }^{+} / \mathrm{L}$ & $1.20-1,98$ & $0.09-0.28$ \\
\hline Permanganate index & $\mathrm{mgO}_{2} / \mathrm{L}$ & $11.0-18.1$ & $4.7-5.0$ \\
\hline TOC $( \pm 0.05)$ & $\mathrm{mgC} / \mathrm{L}$ & $14.00-20.00$ & $7.00-11.00$ \\
\hline
\end{tabular}




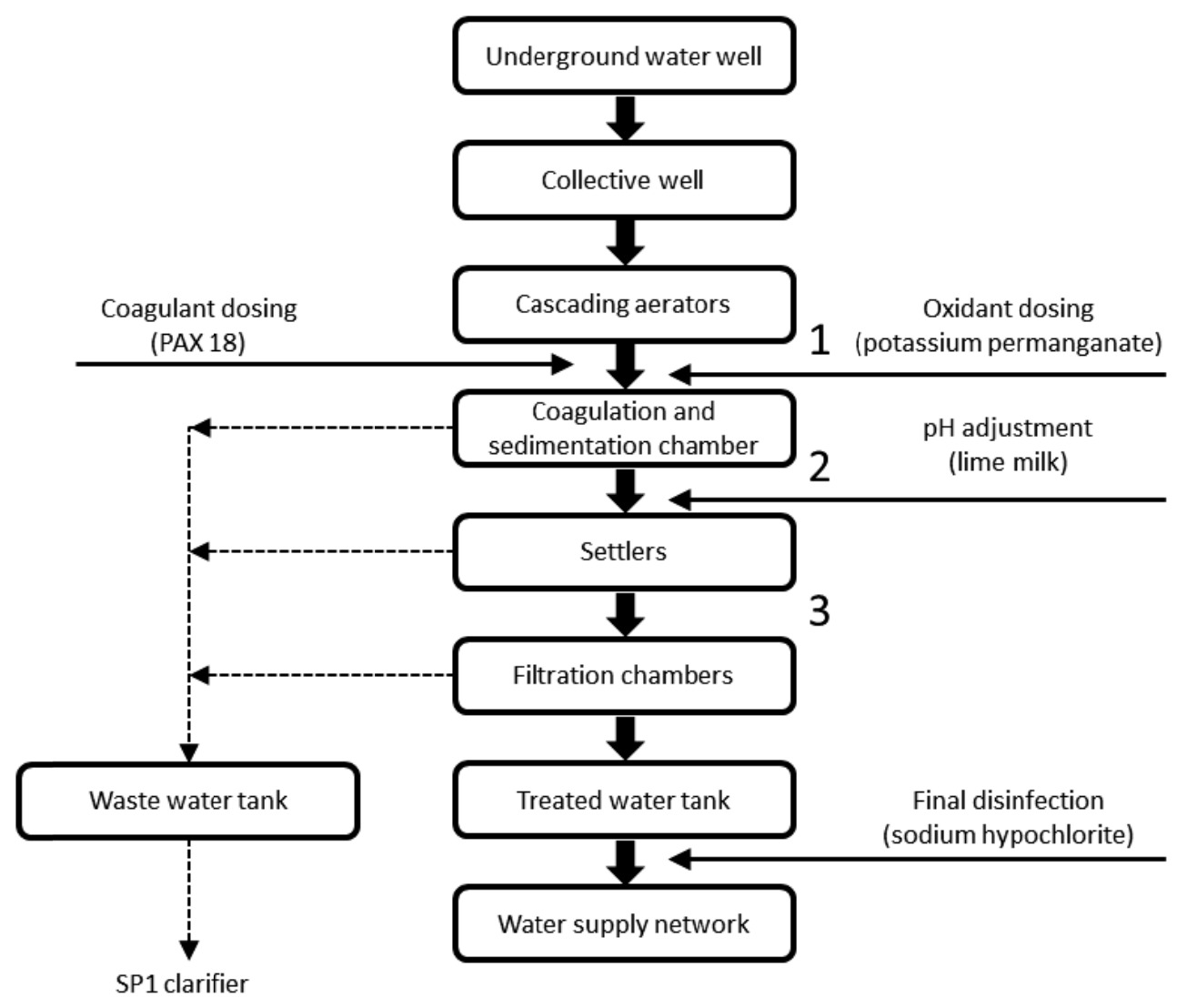

Fig. 1. Technological flowchart for the Water Treatment Plant (1,2,3-place of dosing powdery activated carbon during the tests)

sand with a height of $1.0 \mathrm{~m}$, whereas the top layer was anthracite with a height of $0.4 \mathrm{~m}$. Both of these layers were taken from the bed of filters operating in the station. Water was supplied to the sedimentation tanks on the model filter (Fig. 2, 3-point laboratory testing), to which a powdery activated carbon was added. The type and dose of carbon were selected on the basis of laboratory tests. Two activated carbons: CWZ-30 and Norit Sa Super were selected, both at a dose of $20 \mathrm{mg} / \mathrm{L}$. The filtration speed fluctuated in the range of $1.5-2 \mathrm{~m} / \mathrm{h}$. The filtration cycle lasted until the appearance of PAC in the leakage, thus piercing the bed. The filter was then rinsed with water and air. The effectiveness of the introduction of PAC prior to the filtration process was analyzed for TOC concentration reduction. The results of the conducted filtration were obtained and compared with the quality of raw water and water on filters working on the WTP.

\section{Research in technical scale}

Research in technical scale lasted for six weeks and was carried out on a single filter chamber which was excluded from the operation of the filter chamber. CWZ-30 dosed powdery activated carbon with an optimum dose of $20 \mathrm{mg} / \mathrm{L}$ which was directed to the water and into the filtration chamber. The purpose of the research in technical scale was to confirm the efficiency of water purification, evaluation of the efficiency of rinsing and operation of the filter chamber. The effectiveness of the addition before PAC filtration was analyzed in the aspect of lowering the TOC concentration. Analysis was carried out two times per week. Evaluation of the effectiveness of the process was carried out on the basis of the average value of the TOC concentration (calculated from 16 measurements) in the treated water.

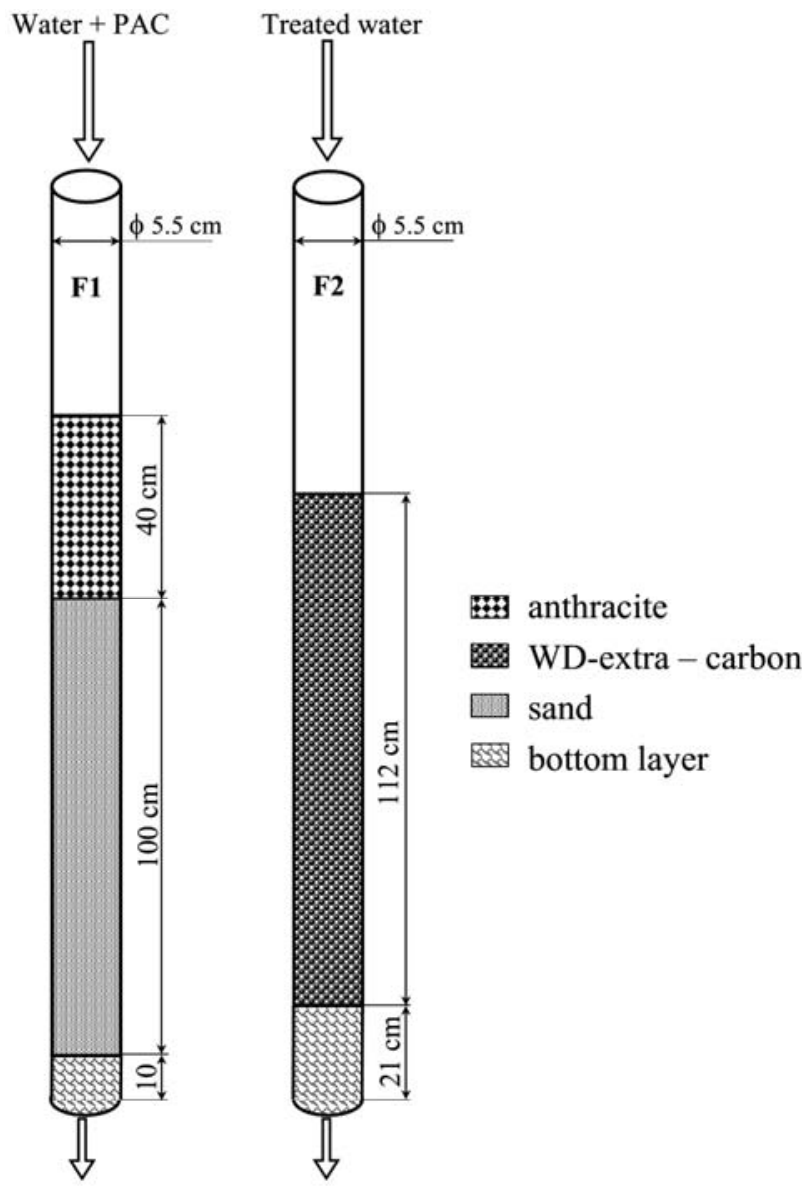

Fig. 2. Diagram of the filter models 


\section{Research on the bio-sorption model filter}

The bio-sorption filter was filled with a bed of WD-extra granular activated carbon and constituted II $^{0}$ filtration, supplied with treated water at the WTP station. The bio-filter F2 filling was chosen earlier by the authors of the study, indicating that WD-extra carbon proved to be the most effective in regard to the removal of organic matter in the sorption processes (Kaleta et al. 2015). The bio-filter was supplied with treated water. The operating parameters of the bio-filter F2 (Fig. 2) were as presented in Table 2. Analyses were carried out for water supply and water after the bio-filtration process in terms of TOC, colour, turbidity, permanganate index and dissolved oxygen. Bio-filter operational assessment was carried out on the basis of EMS tests.

The EMS test is based on determining the value of the $\mathrm{S}$ index of the specified ratio of changes in COD or permanganate index to the loss of dissolved oxygen DO.

$$
S=\frac{\triangle C O D}{\triangle \mathrm{DO}}
$$

If:

$\mathrm{S}=1$ adsorption and biodegradation occurs with the same intensity

$\mathrm{S}>1$ adsorption dominates

$\mathrm{S}<1$ biodegredation dominates

$\mathrm{S}=0, \Delta \mathrm{COD}=0, \Delta \mathrm{DO}>0$ stop processes of sorption and biodegradation $\mathrm{S}$ unmarked, $\Delta \mathrm{COD}>0, \Delta \mathrm{DO}=0$ sorption occurs, lack of biodegradation

$\Delta \mathrm{COD}=0, \Delta \mathrm{DO}=0$ lack of sorption and biodegradation.

\section{Results and discussion}

\section{The effectiveness of treating water by means of powdery active carbons}

The composition of the water used in the research, collected in step 1 was as follows: colouring $40-60 \mathrm{mgPt} / \mathrm{L}$, the permanganate index of 13-14 $\mathrm{mgO}_{2} / \mathrm{L}$, TOC $14.50-16.30 \mathrm{mgC} / \mathrm{L}$ (Table 3). After the addition of powdery activated carbons, a significant reduction of organic matter was obtained (Fig. 3).

Table 2. Parameters of the biofilter model and filter material

\begin{tabular}{|l|l|l|l|}
\hline \multicolumn{2}{|c|}{ Operating parameters } & \multicolumn{2}{c|}{ Physical and chemical properties of the filter material } \\
\hline Height of the carbon bed, $\mathrm{m}$ & 1.12 & Granulation WD-Extra, $\mathrm{mm}$ & $1-4$ \\
\hline Diameter, $\mathrm{m}$ & 0.055 & Specific surface, $\mathrm{m}^{2} / \mathrm{g}$ & $950-1050$ \\
\hline Filtration velocity, $\mathrm{m} / \mathrm{h}$ & $1.5-2.0$ & The iodine value, $\mathrm{mg} / \mathrm{g}$ & $900-1000$ \\
\hline Contact time, $\mathrm{h}$ & 0.5 & $\mathrm{pH}$ aqueous extract & 10.4 \\
\hline
\end{tabular}

Table 3. Physicochemical parameters of water after individual technological processes

\begin{tabular}{|l|c|c|c|c|c|c|}
\hline \multirow{2}{*}{ Parameter } & \multirow{2}{*}{ Unit } & \multicolumn{4}{|c|}{ The range of values } \\
\cline { 3 - 7 } & & untreated water & $1^{*}$ & $2^{*}$ & $3^{*}$ & treated water \\
\hline Colour & $\mathrm{mgPt} / \mathrm{L}$ & $40-100$ & $40-60$ & 20 & 20 & $10-16$ \\
\hline $\mathrm{pH}$ & - & $6.4-7.0$ & $6.6-7.4$ & $8.0-8.2$ & $8.0-8.2$ & $7.8-8.1$ \\
\hline Permanganate index & $\mathrm{mgO}_{2} / \mathrm{L}$ & $11.0-18.1$ & $13.0-14.0$ & 12.0 & 5.6 & $4.7-5.0$ \\
\hline TOC $( \pm 0.05)$ & $\mathrm{mgC/L}$ & $11.00-14.50$ & $14.40-16.30$ & 11.90 & 9.60 & $7.00-16.80$ \\
\hline
\end{tabular}

* 1 - Point at the beginning of the technological process after the addition of the oxidant and the coagulant, 2 - Point before the settlers and after the adjustment of $\mathrm{pH}, 3$ - Point after the settlers, before precipitous filters

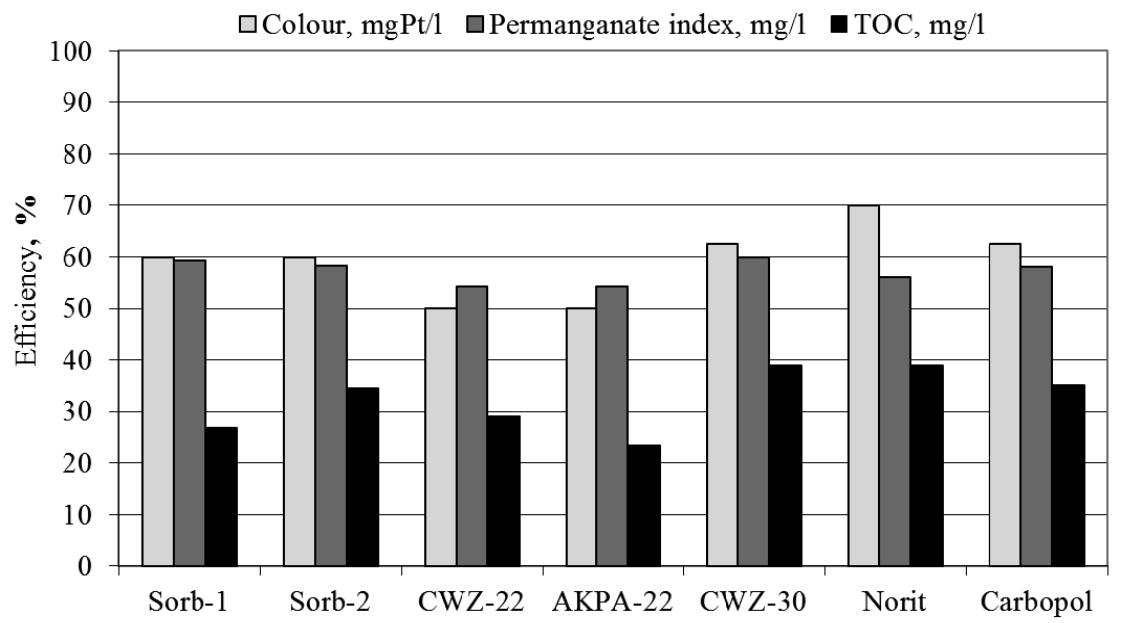

Fig. 3. Efficiency of removal of organic compounds - water after adding an oxidant and coagulant (point 1) 
Reduction of colouring ranged from 50 to $70 \%$, the permanganate index was within $54.3-60 \%$ and the TOC in the range of $23.4-39 \%$. The best results were obtained using CWZ-30 and Norit carbon after application and whose TOC index value amounted to 8.9 and $8.4 \mathrm{mgO}_{2} / \mathrm{L}$.

In step 2 of the process, the water was characterized by the following arrangement: colouring $20 \mathrm{mgPt} / \mathrm{L}$, permanganate index of $12 \mathrm{mgO}_{2} / \mathrm{L}$, TOC $11.90 \mathrm{mgC} / \mathrm{L}$. The sorption organic pollutants proceeded in a less effective manner (Fig. 4).

In this series of tests, reducing the analyzed indicators varied within the following limits: colouring $0-25 \%$, permanganate index $41.6-45 \%$, TOC 5-17.6\%.

Similarly to the previous stage of research, CWZ-30 and Norit carbon have proven to be the most effective carbons; however, the results obtained were much lower than point 1 . The TOC values after the application of the carbon were 9.8 and $9.9 \mathrm{mg} \mathrm{C} / \mathrm{L}$, respectively.

Organic compound indicators in water collected in section 3 accepted the following values: colouring 20 Hazen, permanganate index of $5.6 \mathrm{mg} \mathrm{O}_{2} / \mathrm{L} \mathrm{TOC} 9.6 \mathrm{mg} \mathrm{C} / \mathrm{L}$ (Table $3)$. The results obtained from the use of powdery activated carbons are shown in Figure 5.

After adding the powdery activated carbon to water before filters, the compound indicators characterizing the content of organic compounds were reduced respectively: colouring $-25-75 \%$, the permanganate index $-1.8-47 \%$, TOC $-2-40 \%$. The greatest reduction of colouring and TOC was obtained by using CWZ-30 carbon. In the case of the permanganate index, the effectiveness of CWZ-30 and Norit were comparable.

Research undertaken has shown that the most effective powdery activated carbons in removing the organic matter are CWZ-30 and Norit.

Organic compounds are best removed during the insertion of carbon into the water after the addition of an oxidant and coagulant - point 1 . Slightly worse, but comparable performance was achieved for the water before precipitous filters - point 3 . The process of sorption was worst during the dosage of carbon into the water, before the settlers and after adjusting $\mathrm{pH}$ using $\mathrm{Ca}(\mathrm{OH})_{2}$ (Fig. 6 and Fig. 7). This fact is confirmed in the literature; sorption of pollutants takes place less efficiently in an alkaline environment (Kaleta et al. 2013).

Due to technical conditions prevailing in the analyzed underground water treatment plant (WTP), dosing the powdery activated carbon into the water after settlers (before the filter) was easier. The dosage site was selected as the most suitable for the pilot-scale studies on the filter model and studies on a technical scale.

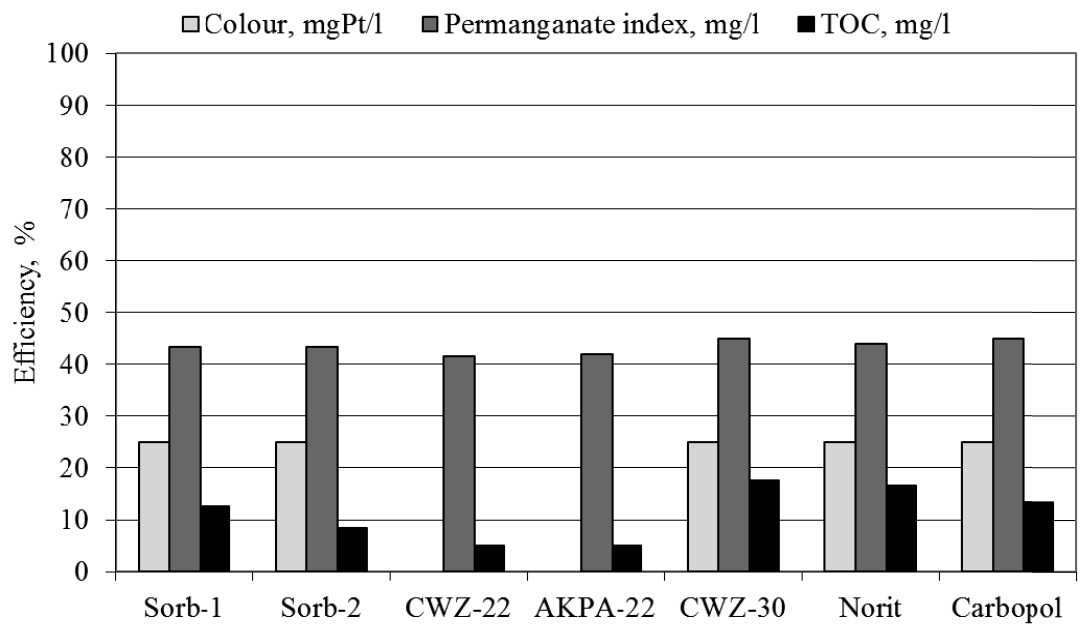

Fig. 4. Efficiency of removal of organic compounds - water before settlers and after adjusting pH (point 2)

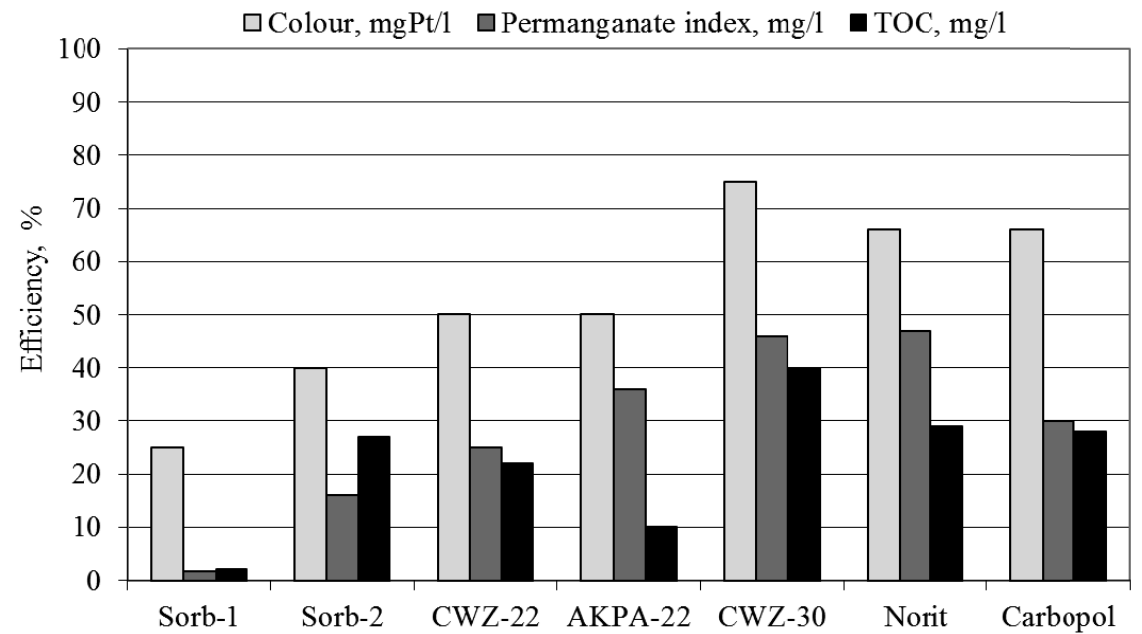

Fig. 5. Efficiency of removal of organic compounds -water before precipitous filters (point 3 ) 


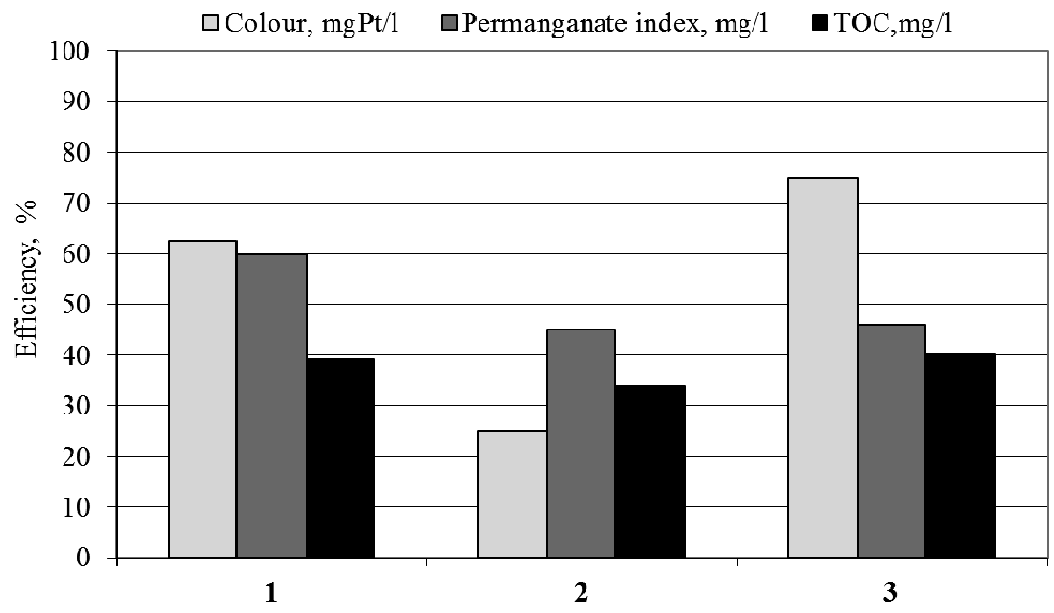

Fig. 6. The efficiency of the removal of organic compounds depending on the dosing sites of CWZ-30 carbon ( 1 - Point at the beginning of the technological process after the addition of the oxidant and the coagulant, 2 - Point before the settlers and after the adjustment of $\mathrm{pH}, 3$ - Point after the settlers, before precipitous filters)

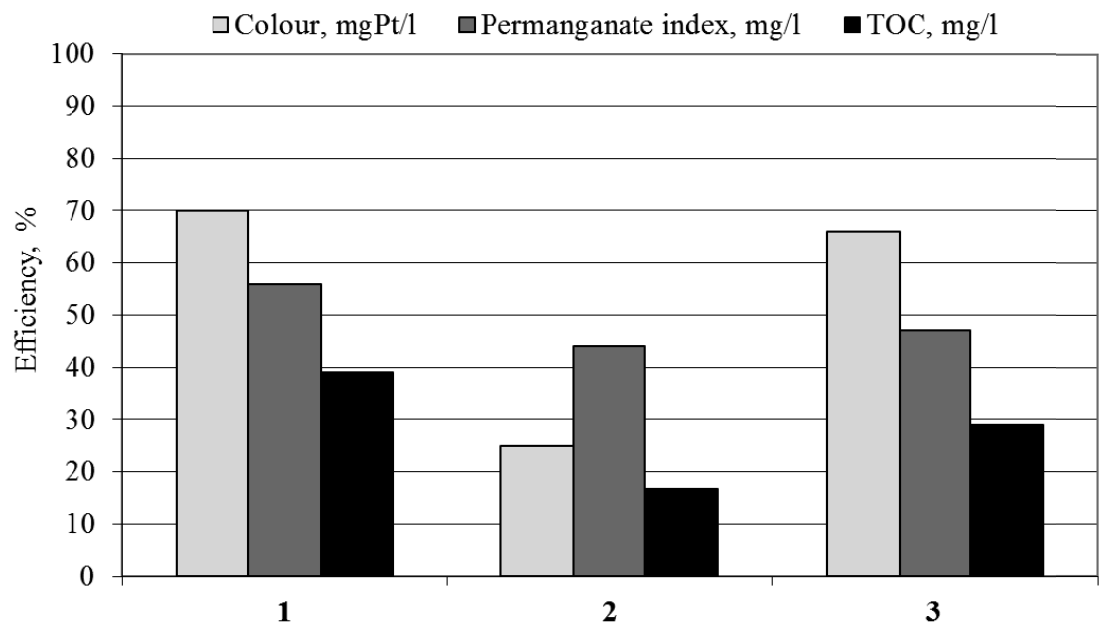

Fig. 7. The efficiency of the removal of organic compounds depending on the dosage site of Norit carbon ( 1 - Point at the beginning of the technological process after the addition of the oxidant and the coagulant, 2 - Point before the settlers and after the adjustment of $\mathrm{pH}, 3$ - Point after the settlers, before precipitous filters)

\section{Analysis of the model filter operation}

TOC concentrations in the water after filters at the station and after the model filter are shown in Table 1. The percentage of organic compounds removed (efficiency process) was calculated relative to the TOC concentration in the raw water during the tests amounting to $13.1 \mathrm{mgC} / \mathrm{L}$. In real terms, the reduction of TOC was $22.1 \%$. After entering the dusty fraction of activated carbons and conducting filtration through a model, more than double the TOC concentration reduction was obtained. The effectiveness of the carbon was comparable. TOC removal rates with the addition of PAC were as follows: for CWZ; $30-48.9 \%$ for Norit SA Super $-46.6 \%$ (Table 4).

Comparing the concentration of TOC in the water to the filter station with the results obtained on the model filter, it appeared that there was a TOC reduction of $31-34 \%$ activated carbon organic compounds and it was retained in the bed. Unfortunately, this resulted in a shortening cycle of filter (from 7 to 4 days) and the possibility of uncontrolled breakthrough of the bed stopping the active carbon. There is always the risk of penetrating the bed in this case, therefore, for safety reasons, dosing of powdery activate carbon in technical conditions is recommended before settling tanks.

Summing up the research in pilot-plant scale, it can be stated that in order to increase the efficiency of TOC removal to treatment technologies it is necessary to introduce the sorption process on the powdery active carbons.

\section{Research in technical scale}

The effectiveness of using PAC in the technical conditions is shown in Table 5. The addition of powdery activated carbon (carbon cannot be put before the settlers) before the chamber filter to the technological system resulted in a decrease of organic matter present in the water by about 10 to $21 \%$. Smaller TOC removal efficiency (average 14.8\%) in the technical conditions could result from the difficulties in precise dosing of carbon dust (imperfect mixing, clogging pumps, valves and pipes supplying coal slurry). 


\section{Analysis of bio-filter operation}

The measures taken towards the reduction of TOC content in the treated water through the use of a second stage filtration with granular activated WD-extra carbon proved to be effective. TOC concentration at the outlet of the filter for a period of approx. 6 months (184 days) was within a range of $0-1 \mathrm{mg}$ C/L (Fig.8). Starting from the $170^{\text {th }}$ day, the filter operation showed an increase in TOC after filtration to the value of about $3 \mathrm{mgC} / \mathrm{L}$. Over the next two months, the filter operation of TOC content in filtered water stabilized at a level of 3-4 mg C/L. However, this was still lower than the current value obtained for the WTP. A systematic study of the filtration bed confirmed the growth of microorganisms, which gradually involved the cycle of transformation of organic matter (Papciak et al.2016). The increasing share of microorganisms in the removal of organic matter rendered the evolution of the $\mathrm{S}$ indicator. The value from the $170^{\text {th }}$ day of filter operation was lesser than 1 , indicating a biodegradable advantage over the sorption process (Fig. 9). The analyzed groundwater can be effectively devoid of organic matter on the second degree of filtration on biologically active carbon filters. The organic compounds in the purified water were $100 \%$ absorbable and $70 \%$ biodegradable. The combination of sorption process with biodegradation up to the moment of exhaustion of the sorption capacity of the activated carbon enabled the work in the initial stage of the carbon bed to remove organic matter within approx. $100 \%$. The colouring of water after the bio-filtration process did not exceed $5 \mathrm{mgPt} / \mathrm{L}$. Other water parameters such as turbidity and the permanganate index were below the limit of quantification (Table 6). Despite the unfavorable development of the biofilm water temperature targeting the bio-filter (about $11^{\circ} \mathrm{C}$ ) there is a smooth transition from the sorption process in bio-sorption. The formation of biofilm allows to extend the filtration cycle and reduce the TOC content by $70 \%$ i.e. from $10 \mathrm{mgC} / \mathrm{L}$ to $3-4 \mathrm{mgC} / \mathrm{L}$. The remaining organic carbon was not biodegradable.

Biological changes are often slow, but due to the adsorption qualities of carbon, particles of organic compound may function on the coal surface for long periods of time. Along with gradual depletion of carbon sorption capacity, the microorganism biomass takes over its function, sorbing the substances present in water. The organic compounds cumulated in the biomass are used for growth and breathing. Also a systematic growth of the number of bacteria populating the biofilter filling has been observed (Papciak el al. 2016). The total number of mesophilic bacteria did not go over $5 \mathrm{fcu} / \mathrm{ml}$ and total number of psychrophilic bacteria did not go over $14 \mathrm{fcu} / \mathrm{ml}$ in water after the biofiltration process (Table 6). A small number of bacteria in the water after biofiltration and the fluid transition from sorption to biodegradation is a proof of well - chosen parameters for the operation of the bioactive filter.

Table 4. Filtration efficiency in the reduction of TOC

\begin{tabular}{|c|c|c|}
\hline Type of filtration & TOC $\pm 0.05(\mathrm{mgC} / \mathrm{L})$ & Effectiveness $(\%)$ \\
\hline Water after filters working on WTP & 10.20 & 22.1 \\
\hline Norit Sa Super and filtration on the model filter & 7.00 & 46.6 \\
\hline CWZ-30 and filtration on the model filter & 6.70 & 48.9 \\
\hline
\end{tabular}

Table 5. Lowering the TOC using CWZ-30 carbon

\begin{tabular}{|c|c|c|c|}
\hline $\begin{array}{c}\text { TOC }( \pm 0.05) \\
{[\mathrm{mgC} / \mathrm{L}]}\end{array}$ & Well water & $\begin{array}{c}\text { Without CWZ-30 } \\
\text { Water treatment }\end{array}$ & $\begin{array}{c}\text { Treated water supplemented with } \\
\text { CWZ-30 }\end{array}$ \\
\hline Min. & 16.1 & 9.39 & 7.45 \\
\hline Max. & 17.2 & 11.20 & 9.84 \\
\hline Av. & 16.6 & 10.37 & 8.82 \\
\hline
\end{tabular}

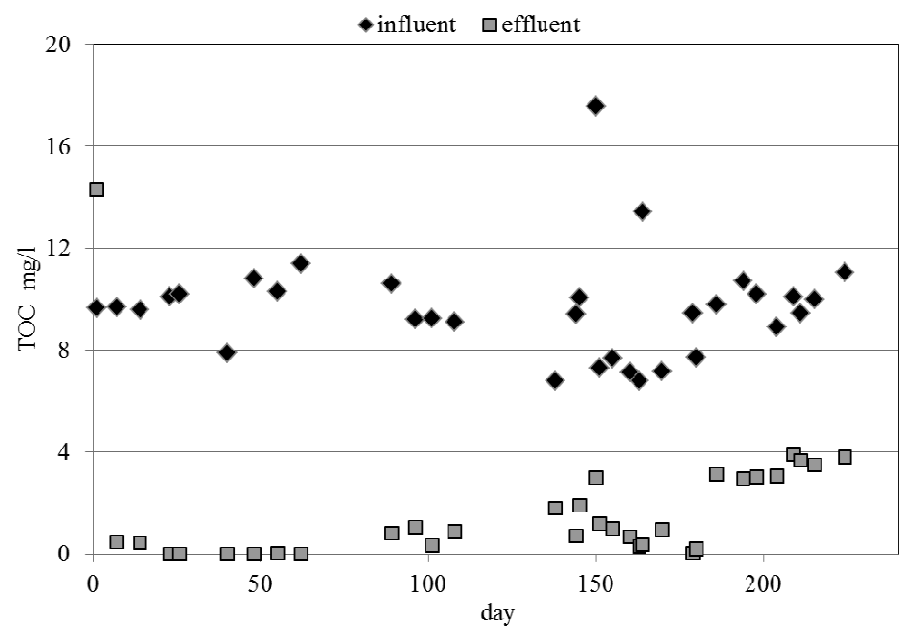

Fig. 8. Changes in organic matter content in water subjected to biofiltration process on model filter 


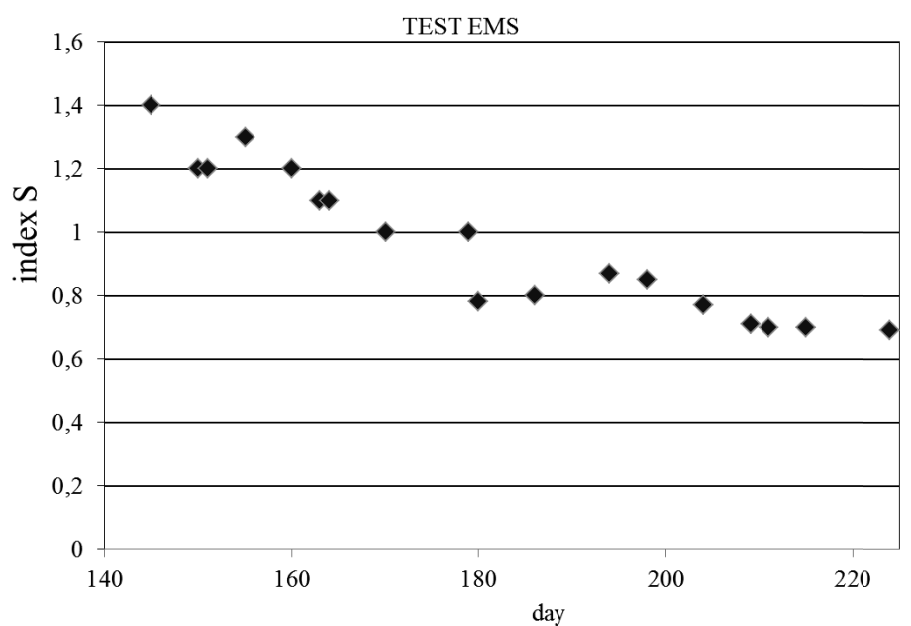

Fig. 9. Changes of $S$ indicator during water filtration on WD-extra granulated active carbon

Table 6. Changes in water parameters in the process of biofiltration (after 140 days of operation of the bed, 71 measuring points )

\begin{tabular}{|c|c|c|c|}
\hline \multicolumn{2}{|c|}{ Parameter } & Influent & Effluent \\
\hline \multirow{5}{*}{$\begin{array}{c}\mathrm{TOC} \\
{[\mathrm{mgC} / \mathrm{L}]}\end{array}$} & Min. & 7.56 & 0.3 \\
\hline & Max. & 14.60 & 3.9 \\
\hline & AV. & 8.95 & 1.97 \\
\hline & Med. & 8.61 & 1.90 \\
\hline & SD & 1.43 & 1.41 \\
\hline \multirow{5}{*}{$\begin{array}{c}\mathrm{DO} \\
{\left[\mathrm{mgO}_{2} / \mathrm{L}\right]}\end{array}$} & Min. & 7.67 & 2.77 \\
\hline & Max. & 8,94 & 7.63 \\
\hline & AV. & 8.36 & 4.46 \\
\hline & Med. & 8.3 & 3.2 \\
\hline & SD & 0.52 & 1.42 \\
\hline \multirow{5}{*}{$\begin{array}{l}\text { Permanganate index } \\
{\left[\mathrm{mgO}_{2} / \mathrm{L}\right]}\end{array}$} & Min. & 4.9 & 0.9 \\
\hline & Max. & 4.9 & 1 \\
\hline & AV. & 4.9 & 0,9 \\
\hline & Med. & 4.9 & 0,9 \\
\hline & SD & 0 & 0.05 \\
\hline \multirow{5}{*}{$\begin{array}{l}\text { Colour } \\
{[\mathrm{mgPt} / \mathrm{L}]}\end{array}$} & Min. & 5 & 0 \\
\hline & Max. & 16 & 5 \\
\hline & AV. & 11.9 & 1.63 \\
\hline & Med. & 12 & 0 \\
\hline & SD & 3.23 & 1.89 \\
\hline \multirow{5}{*}{$\begin{array}{l}\text { Turbidity } \\
\text { [NTU] }\end{array}$} & Min. & 0.24 & 0.76 \\
\hline & Max. & 0.75 & 0.19 \\
\hline & AV. & 0.47 & 0.42 \\
\hline & Med. & 0.47 & 0.40 \\
\hline & SD & 0.13 & 0.13 \\
\hline \multirow{5}{*}{$\begin{array}{l}\text { Temperature } \\
{ }^{\circ} \mathrm{C}\end{array}$} & Min. & 9.1 & 9.6 \\
\hline & Max. & 12.1 & 14.5 \\
\hline & AV. & 10.6 & 11.5 \\
\hline & Med. & 10.6 & 11.3 \\
\hline & SD & 0.78 & 1.52 \\
\hline
\end{tabular}




\begin{tabular}{|c|c|c|c|}
\hline \multicolumn{2}{|c|}{ Parameter } & Influent & Effluent \\
\hline \multirow{3}{*}{$\begin{array}{c}\text { Total number } \\
\text { of mesophilic bacteria } \\
37^{\circ} \mathrm{C} \\
{[f \mathrm{fcu} / \mathrm{ml}]}\end{array}$} & Min. & 0 & 0 \\
\cline { 2 - 4 } & Max. & 8 & 2 \\
\cline { 2 - 4 } & $\mathrm{AV}$. & 2 & 1 \\
\cline { 2 - 4 } & Med. & 2.5 & 2 \\
\cline { 2 - 4 } & $\mathrm{SD}$ & 0 & 0 \\
\cline { 2 - 4 } $\begin{array}{c}\text { Total number } \\
\text { of psychrophilic bacteria } \\
22^{\circ} \mathrm{C} \\
{[\mathrm{fcu} / \mathrm{ml}]}\end{array}$ & Min. & 43 & 14 \\
\cline { 2 - 4 } & Max. & 8 & 5 \\
\cline { 2 - 4 } & $\mathrm{AV}$. & 3 & 5 \\
\cline { 2 - 4 } & Med. & 12 & 4 \\
\hline
\end{tabular}

\section{Conclusions}

Introduction of the technological process to water collected from three different points carried out at the WTP sorption process with the use of powdery active carbons resulted in a more effective removal of organic matter. During laboratory tests, CWZ-30 and Norit proved to be the best carbons.

The best results were obtained when carbon was dosed into the water collected at the beginning of the technological process (after adding oxidant and coagulant), the rate of TOC decreased by approx. 39\%. Slightly worse but comparable performance was achieved for the water taken in the settlers (before precipitous filters), TOC reduction ranged from $29-40 \%$. The adsorption process proceeded worst at a dosage of carbon for water taken after settling tanks for $\mathrm{pH}$ adjustment with help of $\mathrm{Ca}(\mathrm{OH})_{2}$. TOC reduction amounted to $17-34 \%$.

The $\mathrm{pH}$ of water had an impact on the efficiency of sorption process. The best results were obtained for the water at $\mathrm{pH}=6.6-7.4$, taken at the beginning of the technological system, which was consistent with the literature reports (Kaleta et al. 2013).

Research conducted in a pilot-scale confirmed the results obtained in the laboratory. The concentration of TOC in the water to the filter station was increased by $31-34 \%$ compared to the addition of the powdery active carbons and filtration through a model. The tested dusty activated carbons gave comparable results. These absorbed organic compounds are retained in the bed. However, this resulted in a shortening filter cycle (from 7 to 4 days) and the possibility of uncontrolled piercing of deposits.

Research on a technical scale did not confirm such a high removal efficiency of organic matter, which was obtained at the laboratory scale and pilot scale. The effectiveness of TOC reduction was smaller and amounted to an average of about $15 \%$ in relation to the currently obtained at the WTP.

Groundwater may be effectively devoid of organic matter in the second degree of filtration on biologically active carbon filters in which the organic compounds in the purified water was $70 \%$ biodegradable. The concentration of TOC after the second stage of bio-filtration on granular activated carbon did not exceed the value of $4.0 \mathrm{mg} \mathrm{C} / \mathrm{L}$.

In view of the fact that the parameters of the biofilter were well matched, and physico-chemical quality of water supplied to the biofilter was stable and conducive to the development of biofilm ( $\mathrm{pH}$, oxygen); the only parameter which could improve the effectiveness of the process is the temperature. However, its increase in technical conditions is economically unjustified.

\section{References}

Adamski, W. \& Szlachta, M. (2011). Technologies removal of natural organic matter occurring in the waters, Technologia Wody, 1 (9), pp. 17-21. (in Polish)

Bodzek, M. \& Rajca, M. (2013). Photocatalysis in the treatment and disinfection of water. Part II, Removal of metals and natural organic matter, Technologia Wody, 11 (31), pp.18-30. (in Polish)

Grzegorczuk-Nowacka, M. (2011). Humic substances - structure, properties and importance in the process water treatment, Technologia Wody, 4 (18), pp. 20-27. (in Polish)

Górka, A., Papciak, D., Zamorska, J. \& Antos, D. (2008). The influence of biofilm on the effectiveness of ion exchange process, Industrial \& Engineering Chemistry Research, 47, pp. 7456-7664.

Holc, D., Pruss, A., Michałkiewicz, M. \& Cybulski, Z. (2016). Effectiveness of organic compounds removing during water treatment by filtration through a biologically active carbon filter with the identification of microorganisms, Annual Set The Environment Protection, 18, pp. 235-246.

Hur, J., Williams, M.A. \& Schlautman, M.A. (2006). Evaluating spectroscopic and chromatographic techniques to resolve dissolved organic matter via end member mixing analysis, Chemosphere, 63, pp. 387-402.

Jasper, A., Salih, H.H., Sorial, G.A., Sinha, R., Krishnan, R. \& Patterson, C.L. (2010). Impact of nanoparticles and natural organic matter on the removal of organic pollutants by activated carbon adsorption, Environmental Engineering Science, 27 (1), pp. 85-93, DOI: 10.1089/ees.2009.0234.

Kalda, G. \& Murias, J. (2015). Analysis of underground water contamination with industrial waste products in the territory of Podkarpacie region, Journal of Civil Engineering, Environment and Architecture, T. XXXII, z. 62 (3/I/15), pp. 191-206. (in Polish)

Kaleta, J., Papciak, D. \& Puszkarewicz, A. (2015). Removal of Mospilan 20SP pesticide from its aqueous solutions by coagulation and adsorption, Przemyst Chemiczny, 96, 6, pp. 906-911.

Kaleta, J., Papciak, D. \& Puszkarewicz, A. (2013). Assessment of usability of bentonite claus from removing phenol from water solutions, Annual Set The Environment Protection, 15, pp. 2352-2368.

Kim, H. \& Yu, M. (2007). Characterization of aquatic humic substances to DBPs formation in advanced treatment processes for conventionally treated water, Journal of Hazardous Materials, 143, pp. 486-493.

Kovalova, L., Detlef, R., Knappe, U., Lehnberg, K., Kazner, Ch. \& Hollender, J. (2013). Removal of highly polar micropollutants 
from wastewater by powdered activated carbon, Environmental Science and Pollution Research, 20, 6, pp. 3607-3615.

Meinel, F., Ruhl, A. S., Sperlich, A., Zietzschmann, F. \& Jekel, M. (2015). Pilot-scale investigation of micropollutant removal with granular and powdered activated carbon, Water, Air, \& Soil Pollution, DOI 10.1007/s11270-014-2260-y.

Papciak, D., Kaleta, J., Puszkarewicz, A. \& Tchórzewska-Cieślak, B. (2016). The use of biofiltration process to remove organic matter from groundwater, Journal of Ecological Engineering, 17, 3, pp. 119-124, DOI: 10.12911/22998993/63481

Pisarek, I. \& Głowacki, M. (2015). Quality of groundwater and aquatic humic substances from main reservoir ground water No. 333, Journal of Ecological Engineering, 16, 5, pp. 46-53.
Rosińska, A. \& Rakocz, K. (2013). The role of the biodegradable organic matter in the water disinfection, Inżynieria i Ochrona Środowiska, 16, 4, pp. 511-521. (in Polish)

Skoczko, I., Piekutin, J., Szatyłowicz, E. \& Niedźwiecka, M. (2016). Removal of boron from groundwater by filtration through selected filter bed materials, Rocznik Ochrona Środowiska, 18, pp. 861-872.

Tchórzewska-Cieślak, B. (2012). Urban Water Safety Management. 5th International Conference on Safety and Environment in the Process and Power Industry (CISAP) Location: Milano, ITALY JUN 03-06, Chemical Engineering Transactions 26, pp. 201-206.

\section{Zastosowanie pylistych węgli aktywnych do usuwania materii organicznej z wody podziemnej}

Streszczenie: $\mathrm{W}$ artykule przedstawiono wyniki badań w skali laboratoryjnej, półtechnicznej i technicznej nad wprowadzeniem do istniejącego układu technologicznego stacji uzdatniania wody podziemnej, pylistego węgla aktywnego. Celem badań było obniżenie zawartości występujących w wodzie uzdatnionej związków organicznych, które po procesie dezynfekcji chlorem tworzą toksyczne związki chloroorganiczne (THM). W skali laboratoryjnej przebadano 9 rodzajów pylistych węgli aktywnych, z których dwa najlepsze wytypowano do dalszych badan. Badania w skali półtechnicznej realizowano na filtrze modelowym z zastosowaniem węgli: CWZ-30 i Norit Sa Super. Obniżenie materii organicznej w stosunku do jej dotychczasowej zawartości w wodzie uzdatnionej wynosiło ok.30\%. Badania w skali technicznej z zastosowaniem węgla CWZ-30 wykazały nieco mniejszą skuteczność w odniesieniu do badań laboratoryjnych i badań w skali półtechnicznej. Obniżenie zawartości materii organicznej wyniosło ok. $15 \%$. Ponieważ ostatnim procesem jednostkowym przed dezynfekcją jest filtracja, zaproponowano alternatywne rozwiązanie - drugi stopień filtracji ze złożem granulowanego węgla aktywnego, pracującego w połączonych procesach sorpcji i biodegradacji. Rezultaty badań zrealizowanych w skali półtechnicznej były w pełni zadowalające - skuteczność 70-100\%. 